\title{
National Workload Analysis of Network of Drug Information Centers at Ministry of Health Hospitals in Saudi Arabia
}

\author{
Yousef Ahmed Alomi ${ }^{1}$ * (iD, Saeed Jamaan Alghamdi², Radi Abdullah Alattyh ${ }^{2}$ \\ ${ }^{I}$ The Past General Manager of General Administration of Pharmaceutical Care, The Past Head, National Clinical \\ pharmacy and pharmacy practice, The Past Head, Pharmacy $R$ and D Administration, Ministry of Health, Riyadh, \\ SAUDI ARABIA. \\ ${ }^{2}$ General Administration of Pharmaceutical Care, Ministry of Health, Riyadh, SAUDI ARABIA.
}

\begin{abstract}
Objectives: To analyze the workload of the network of drug information centers at the Ministry of Health institutions, Saudi Arabia. Methods: This is a 2-month cross-sectional survey of all drug information centers at $\mathrm{MOH}$ hospitals. Any drug information center that has been recently opened or has provided services to the healthcare professionals and the public participated in the survey. The national, regional, and local drug information centers at healthcare institutions were included in the survey. In addition, hospitals or primary care centers (e.g., public, pediatric, maternity, and psychiatry) were also included in the survey. The survey consisted of two parts: demographics data and workload of drug information centers. The clinical activities were driven by the American College of Clinical Pharmacy model. Results: The questionnaire was distributed to around 60 drug information centers. A total of 46 centers responded to the questionnaire, with a response rate of around $76.66 \%$. Most hospitals (11 (23.9\%)) had $100-199$ beds and others (11 (23.9\%)) had 200-299 beds. A total of 1022.5; 22,495; and 269,940 drug information queries were received daily, monthly, and annually, respectively. The greatest demand for a full-time employee (FTE) to preform drug information activities was at the central drug information activities (20.95 FTE) followed by the administration-related drug information activities (17.98 FTE) and patient-specific drug information activities (8.41 FTE). Among the central drug information activities, the highest amount of activity was observed for in-service training (10.95 FTE), whereas among the administration-related drug information activities, the highest amount of activity was observed for attending lectures/courses/symposium/training (2.46 FTE). Among the patient-specific drug information activities, the highest amount of activity was observed for patient counseling services (3.43 FTE). Conclusion: The workload of drug information centers was found to be very high. The services were needed to be revised within basic and advanced requirements of drug information centers at the Ministry of Health, Saudi Arabia.

Key words: Workload, Network, Drug Information Centers, Ministry of Health, Saudi Arabia.
\end{abstract}

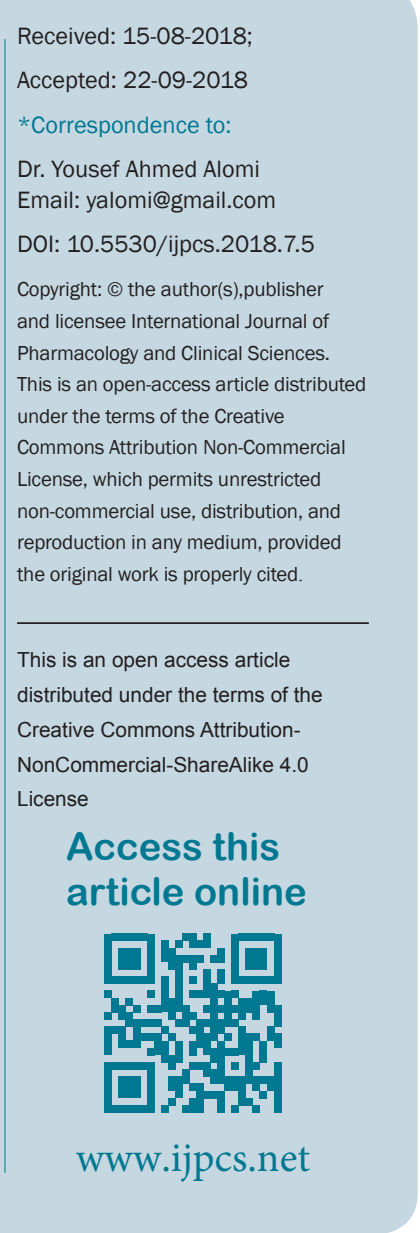

\section{INTRODUCTION}

In early 2013, National Drug Information Center was founded at the Ministry of Health (MOH). ${ }^{1}$ In 2014, the network of drug information centers was spanning over 20 regions with more than 50 centers. ${ }^{2}$ All these centers provide several healthcare services including operative clinical activities. They operate with the help of several basic requirements including equipment, personnel, and administrative services. The drug information centers' human resources is a potential element of such requirements. The calculation of workforce demand is required including the analysis of clinical activities with entire organizations or throughout outsource institutions Several studies have focused their research on cost avoidance of drug information 
services. ${ }^{3-9}$ However, to the best of our knowledge, studies regarding the personal workforce and clinical activities are scarce around the world and in the Middle East countries including Saudi Arabia. Therefore, in this study, we aimed to explore the workload of drug information centers in the Kingdom of Saudi Arabia.

\section{METHODS}

This is a 2-month cross-sectional survey of all drug information centers at $\mathrm{MOH}$ hospitals. Any drug information center that has been recently been opened or has provided services to the healthcare professionals and the public participated in the survey. The national, regional, and local drug information centers at healthcare institutions were included in the survey. In addition, hospitals and primary care centers (public, pediatric, maternity, psychiatry) were also included in the survey. The survey consisted of two parts: demographics data which consisted of several parts: (1) workload of drug information centers; (2) cost analysis of drug information centers' foundations; (3) cost analysis of drug information activity; and (4) questions about education and training activity of drug information centers. The clinical activities are driven by the American College of Clinical Pharmacy (ACCP model of clinical activities. ${ }^{10}$ The central drug information activities, patient-centered drug information activity, and Administrative drug information activities. All calculation were performed by using an electronic Survey Monkey system with emphasis on the workload of drug information centers.

\section{RESULTS}

The survey was distributed to 60 drug information centers with a total responders of 46 ; thus, the response rate was found to be $76.66 \%$. Most hospitals (11 (23.9\%)) had 100-199 beds and others (11 (23.9\%)) had 200-299 beds. Most hospitals were accredited to the Saudi Center for Accreditation of Healthcare Institutions (CBAHI (27 (58.7\%)) and to the Saudi Commission of Health Specialties (9 (19.6\%)), whereas 11 (23.9\%) hospitals were not accredited by any organization. Most of the drug information centers were for adults $(20(43.48 \%))$ and General (15 (32.61\%)) followed by the psychiatric $(5(10.87 \%))$ and pediatrics centers $(4$ (8.7\%)) (Table 1). Among all the responders, 43 (95.6\%) were Saudi and 2 (4.4\%) were non-Saudi responders. Age of most responders (44 (95.7\%)) was in the range of 18-40 years. The highest level of education of the responders was Bachelor of Pharmacy (22 (47.83\%)),
Doctor of Pharmacy (11 (23.9\%)), and Master of Science $(9(19.57 \%))$. Only $4(10 \%)$ responders were certified and specialized in pharmaceuticals. Most of the responders $(30(65.2 \%))$ had $1-6$ years of experience at drug information centers, whereas others eight (17.39 \%) has experience in clinical pharmacy (Tables 2 and $3)$. The total number of drug information queries at all 46 hospitals was $1022.5 ; 22,495$; and 269,940 on daily, monthly, and annually, respectively. Of those, psychiatric (8.93), neonatal critical care (6.84), and medical departments (4.48) received the highest number of daily queries than that of other departments. The pharmacy unit received questions on an average regarding outpatient pharmacy (4.95) and inpatient pharmacy (4.75) per day (Tables 4 and 5). Among the number of drug information queries, 382.5 (37.4\%) queries were received by the head of drug information center, 355 (34.72\%) were received by the pharmacist, and $285(27.87 \%)$ were received by the clinical pharmacist daily at all hospitals. The average time needed to answer a single query was around $9.34 \mathrm{~min}$. A total of ( 0.47 FTE) was needed to answer queries at each center, whereas an average of (1.85 FTE) pharmacist and an average of (2.46 FTE) were needed at each drug information center (Tables 6 and 7). The most available staff member at drug information center was pharmacy technician followed by a regular pharmacist. The average space of drug information center was around $11.72 \mathrm{~m}^{2}$, whereas the pharmacy technician's room and clinical pharmacist's room inside the drug information center had the greatest room size (Table 8 ). The greatest demand for an FTE was for the central drug information activities (20.95 FTE) followed by the administrationrelated drug information activities (17.98 FTE) and the patient-specific drug information activities (8.41 FTE). The highest amount of activity among the central drug information activities was observed for inservice training (10.95 FTE). Furthermore, the highest amount of activity among the administration-related drug information activities was observed for attending lectures/courses/symposium/training (2.46 FTE), and among the patient-specific drug information activities, it was observed for patient counseling services (3.43 FTE) (Table 9).

\section{DISCUSSION}

The network of drug information centers was founded in 2014 after the national drug information center was founded. ${ }^{1,2}$ The network was organized by a central committee of drug information at the General Administration of Pharmaceutical Care at $\mathrm{MOH}$. 


\begin{tabular}{|c|c|c|}
\hline Number of beds at the hospital & Response Count & Response Percent \\
\hline$<50$ & 7 & $15.2 \%$ \\
\hline $50-99$ & 6 & $13.0 \%$ \\
\hline 100-199 & 11 & $23.9 \%$ \\
\hline 200-299 & 11 & $23.9 \%$ \\
\hline 300-399 & 4 & $8.7 \%$ \\
\hline $400-499$ & 4 & $8.7 \%$ \\
\hline$=$ or $>600$ & 3 & $6.5 \%$ \\
\hline Medical City & 0 & $0.0 \%$ \\
\hline Answered question & 46 & \\
\hline Skipped question & 0 & \\
\hline The hospital accreditation & Response Count & Response Percent \\
\hline CIBAHI & 27 & $58.7 \%$ \\
\hline Joint Commotion the USA & 7 & $15.2 \%$ \\
\hline Canada & 1 & $2.2 \%$ \\
\hline Saudi commission on health accreditation & 9 & $19.6 \%$ \\
\hline Non accredited & 11 & $23.9 \%$ \\
\hline Answered question & 46 & \\
\hline Skipped question & 0 & \\
\hline The type of drug information center & Response Count & Response Percent \\
\hline General Drug Information Center & 15 & $32.61 \%$ \\
\hline Adult drug information center & 20 & $43.48 \%$ \\
\hline Pediatric drug information center & 4 & $8.70 \%$ \\
\hline Psychiatric drug information center & 5 & $10.87 \%$ \\
\hline Oncology drug information center & 0 & $0.00 \%$ \\
\hline Cardiology drug information center & 1 & $2.17 \%$ \\
\hline Dental drug information center & 0 & $0.00 \%$ \\
\hline Primary health care drug information center & 1 & $2.17 \%$ \\
\hline Answered question & 46 & \\
\hline Skipped question & 0 & \\
\hline
\end{tabular}

It consists of representatives from 20 regions. The committee comprises specialized clinical pharmacists and trained pharmacists. The network provides essential functions of international standards related to drug information services. ${ }^{11}$ However, till date, the workload of activities of drug information centers has not been studied separately. Most of the studies have focused their research on workload of clinical pharmacy services. ${ }^{10,12}$ The analysis of workload requires the calculation of workforce demand and cost of drug information centers. The authors of this study have tried to explore the workload analysis of drug information services at the $\mathrm{MOH}$ in Saudi Arabia. According to our results, most of the drug information centers were general and for adults followed by the psychiatric and pediatric centers. This is expected because most of the adults or general hospitals had opened these services, whereas not all pediatric or psychiatric hospitals had opened drug information centers. However, it is noteworthy that around 25\% and $5 \%$ of the drug information centers belonged to the psychiatric or pediatrics hospitals, respectively. Most the drug information pharmacists were Saudi nationals with a bachelor's degree; there were a smaller number of pharmcists with Doctor of Pharmacy and Master of Science degree. This is expected because until now, the $\mathrm{MOH}$ hospitals do not have enough number of clinical pharmacists. Alamri et al. also reported similar results with respect to the bachelor's degree, whereas the number of Doctor of Pharmacy and Master of Science degrees more than what reported by Alamri et al because the the current study covered wide range number of regions. ${ }^{13}$ The average number of queries received by the 


\begin{tabular}{|c|c|c|}
\hline Nationality & Response Count & Response Percent \\
\hline Saudi & 43 & $95.6 \%$ \\
\hline Non- Saudi & 2 & $4.4 \%$ \\
\hline Answered question & 45 & \\
\hline Skipped question & 1 & \\
\hline Gender & Response Count & Response Percent \\
\hline $18-40$ years & 44 & $95.7 \%$ \\
\hline $40-65$ years & 2 & $4.3 \%$ \\
\hline $18-40$ years & 0 & $0.0 \%$ \\
\hline more than 65 years & 0 & $0.0 \%$ \\
\hline Answered question & 46 & \\
\hline Skipped question & 0 & \\
\hline Academic Qualification (s): & Response Count & Response Percent \\
\hline Diploma Pharmacy & 7 & $15.22 \%$ \\
\hline Bsc. Pharm & 22 & $47.83 \%$ \\
\hline M.S & 9 & $19.57 \%$ \\
\hline Msc. Clinical Pharmacy & 6 & $13.04 \%$ \\
\hline Pharm.D. & 11 & $23.91 \%$ \\
\hline Ph.D & 0 & $0.00 \%$ \\
\hline MBA & 3 & $6.52 \%$ \\
\hline Pharmacy Residency Two years (R1) & 1 & $2.17 \%$ \\
\hline Pharmacy Residency one year (R2) & 0 & $0.00 \%$ \\
\hline Fellowship & 1 & $2.17 \%$ \\
\hline Others & 1 & $2.17 \%$ \\
\hline Answered question & 46 & \\
\hline Skipped question & 0 & \\
\hline Total years worked as a pharmacist & Response Count & Response Percent \\
\hline Board Certified Ambulatory Care Pharmacist (BCACP) & 0 & $0.0 \%$ \\
\hline Board Certified Critical Care Pharmacist (BCCCP) & 0 & $0.0 \%$ \\
\hline Board Certified Nuclear Pharmacist (BCNP) & 1 & $2.5 \%$ \\
\hline Board Certified Nutrition Support Pharmacist (BCNSP) & 0 & $0.0 \%$ \\
\hline Board Certified Oncology Pharmacist (BCOP) & 0 & $0.0 \%$ \\
\hline Board Certified Pediatric Pharmacy Specialist (BCPPS) & 1 & $2.5 \%$ \\
\hline Board Certified Pharmacotherapy Specialists (BCPS) & 1 & $2.5 \%$ \\
\hline Board Certified Psychiatric Pharmacist (BCPP) & 1 & $2.5 \%$ \\
\hline Non & 39 & $97.5 \%$ \\
\hline Others & 1 & $2.5 \%$ \\
\hline Answered question & 40 & \\
\hline Skipped question & 6 & \\
\hline
\end{tabular}

drug information center was found to be varied. These results agree with those reported by Alomi et al. and are more than what has been reported by Matuszewski et al. ${ }^{2,14}$ Most queries originated from the medical and psychiatric department and neonatal units. This is expected because several drug-related problems, such as adverse events and multiple drug-drug interactions, were related to the general medical and antipsychotic medications. In addition, the other reason could be that the psychiatric hospital must have just started their drug information services. The neonatal department did not have clinical pharmacist, which needs to closely monitor 
Alomi, et al.: National Workload of Network of Drug Information Centers in Saudi Arabia

\begin{tabular}{|c|c|c|c|c|c|}
\hline Answer Options & $\begin{array}{c}\text { Pharmacy } \\
\text { Practice }\end{array}$ & $\begin{array}{c}\text { Clinical } \\
\text { Pharmacy }\end{array}$ & $\begin{array}{c}\text { Pharmacy } \\
\text { Administration }\end{array}$ & $\begin{array}{c}\text { Drug information } \\
\text { services }\end{array}$ & $\begin{array}{c}\text { Response } \\
\text { Count }\end{array}$ \\
\hline 0 & 2 & 7 & 3 & 3 & 13 \\
\hline$<1$ year & 3 & 5 & 4 & 6 & 16 \\
\hline $1-3$ & 8 & 5 & 9 & 14 & 24 \\
\hline $4-6$ & 17 & 3 & 7 & 16 & 28 \\
\hline$>6$ years & 23 & 5 & 11 & 8 & 29 \\
\hline answered question & & & & & 46 \\
\hline skipped question & & & & & 0 \\
\hline
\end{tabular}

\begin{tabular}{|c|c|c|c|c|c|c|}
\hline Answer Options & $\begin{array}{l}\text { The number of } \\
\text { responders is not } \\
\text { received a question }\end{array}$ & $\begin{array}{l}\text { The number of } \\
\text { responders received } \\
\text { a question }\end{array}$ & $\begin{array}{c}\text { Response } \\
\text { Count }\end{array}$ & $\begin{array}{l}\text { Total number } \\
\text { of question } \\
\text { received }\end{array}$ & $\begin{array}{l}\text { Average number } \\
\text { of question per } \\
\text { each hospital }\end{array}$ & FTE \\
\hline Adults Emergency & 9 & 36 & 45 & 195 & 5.42 & 0.011 \\
\hline Pediatrics Emergency & 14 & 31 & 45 & 157.5 & 5.08 & 0.011 \\
\hline Adults Critical Care & 12 & 33 & 45 & 172.5 & 5.23 & 0.011 \\
\hline Pediatrics Critical Care & 22 & 22 & 44 & 115 & 5.23 & 0.011 \\
\hline Neonates Critical Care & 26 & 19 & 45 & 130 & 6.84 & 0.014 \\
\hline Medical & 3 & 42 & 45 & 230 & 5.48 & 0.011 \\
\hline Surgical & 9 & 36 & 45 & 135 & 3.75 & 0.008 \\
\hline Pediatrics & 11 & 34 & 45 & 155 & 4.56 & 0.009 \\
\hline Psychiatry & 24 & 21 & 45 & 187.5 & 8.93 & 0.019 \\
\hline $\begin{array}{l}\text { Obstetrics and } \\
\text { Gynecology }\end{array}$ & 22 & 23 & 45 & 97.5 & 4.24 & 0.009 \\
\hline $\begin{array}{l}\text { Anesthesia and } \\
\text { Operation }\end{array}$ & 24 & 21 & 45 & 97.5 & 4.64 & 0.010 \\
\hline
\end{tabular}

\begin{tabular}{|c|c|c|c|c|c|c|}
\hline Answer Options & $\begin{array}{l}\text { The number of } \\
\text { responders is not } \\
\text { received a question }\end{array}$ & $\begin{array}{l}\text { The number of } \\
\text { responders received } \\
\text { a question }\end{array}$ & $\begin{array}{c}\text { Response } \\
\text { Count }\end{array}$ & $\begin{array}{l}\text { Total number } \\
\text { of question } \\
\text { received }\end{array}$ & $\begin{array}{l}\text { Average number } \\
\text { of question per } \\
\text { each hospital }\end{array}$ & FTE \\
\hline Inpatient pharmacy & 6 & 40 & 46 & 190 & 4.75 & 0.010 \\
\hline IV admixture Pharmacy & 24 & 21 & 45 & 54 & 2.57 & 0.005 \\
\hline Outpatient pharmacy & 4 & 41 & 45 & 203 & 4.95 & 0.010 \\
\hline Satellite pharmacy & 34 & 11 & 45 & 33 & 3.00 & 0.006 \\
\hline Emergency pharmacy & 15 & 30 & 45 & 102 & 3.40 & 0.007 \\
\hline Drug information & 20 & 26 & 46 & 124 & 4.77 & 0.010 \\
\hline Clinical Pharmacy & 25 & 20 & 45 & 87 & 4.35 & 0.009 \\
\hline Preparation area & 20 & 25 & 45 & 90 & 3.60 & 0.008 \\
\hline Prepackaging area & 31 & 12 & 43 & 36 & 3.00 & 0.006 \\
\hline Pharmacy Store & 18 & 27 & 45 & 74 & 2.74 & 0.006 \\
\hline
\end{tabular}




\begin{tabular}{|c|c|c|c|c|c|c|c|}
\hline Answer Options & $\begin{array}{c}\text { Total } \\
\text { number of } \\
\text { question }\end{array}$ & $\begin{array}{l}\text { Average } \\
\text { number } \\
\text { of } \\
\text { question }\end{array}$ & $\begin{array}{c}\text { Response } \\
\text { Count }\end{array}$ & $\begin{array}{l}\text { Total time needed } \\
\text { to answer each } \\
\text { question min }\end{array}$ & $\begin{array}{l}\text { average time } \\
\text { needed to } \\
\text { answer each } \\
\text { question (min) }\end{array}$ & $\begin{array}{c}\text { Response } \\
\text { Count }\end{array}$ & FTE \\
\hline $\begin{array}{l}\text { Head of drug information } \\
\text { center }\end{array}$ & 382.5 & 8.50 & 45 & 425 & 10.89 & 45 & 0.19 \\
\hline Clinical Pharmacist & 285 & 7.13 & 40 & 257.5 & 8.85 & 37 & 0.13 \\
\hline Pharmacist & 355 & 8.45 & 42 & 230 & 8.29 & 38 & 0.15 \\
\hline
\end{tabular}

\begin{tabular}{|l|c|c|c|c|c|}
\hline \multicolumn{2}{|l|}{ Table 7: The total number of staff for drug information centers. } \\
\hline Answer Options & $\begin{array}{c}\text { The number of } \\
\text { responders, not } \\
\text { staff existed }\end{array}$ & $\begin{array}{c}\text { The number of } \\
\text { responders staff } \\
\text { existed }\end{array}$ & $\begin{array}{c}\text { Response } \\
\text { Count }\end{array}$ & $\begin{array}{c}\text { Total number } \\
\text { of staff }\end{array}$ & $\begin{array}{c}\text { Average number } \\
\text { of staff per each } \\
\text { center }\end{array}$ \\
\hline Head of drug information center & 5 & 41 & 46 & 50 & 1.22 \\
\hline Clinical Pharmacist & 32 & 14 & 46 & 24 & 1.71 \\
\hline Pharmacist & 25 & 21 & 46 & 55 & 2.62 \\
\hline Pharmacy technician & 38 & 7 & 45 & 47 & 6.71 \\
\hline Secretary & 39 & 6 & 45 & 6 & 1.00 \\
\hline Porter & 40 & 6 & 46 & 9 & \\
\hline
\end{tabular}

\begin{tabular}{|c|c|c|c|c|c|}
\hline Answer Options & $\begin{array}{l}\text { The number of } \\
\text { responders answered } \\
\text { not existed space }\end{array}$ & $\begin{array}{c}\text { The number } \\
\text { of responders } \\
\text { answered existed } \\
\text { space }\end{array}$ & $\begin{array}{l}\text { Response } \\
\text { Count }\end{array}$ & $\begin{array}{l}\text { The total } \\
\text { size of } \\
\text { DIC space }\end{array}$ & $\begin{array}{c}\text { The average size } \\
\text { of DIC space }\end{array}$ \\
\hline Head of drug information center office & 14 & 32 & 46 & 347 & 10.84 \\
\hline Clinical Pharmacist office & 35 & 9 & 44 & 140 & 15.56 \\
\hline Pharmacist office & 30 & 11 & 41 & 138 & 12.55 \\
\hline Pharmacy technician office & 39 & 5 & 44 & 78 & 15.60 \\
\hline Secretary office & 39 & 6 & 45 & 37 & 6.17 \\
\hline Porter Office & 38 & 6 & 44 & 65 & 10.83 \\
\hline ALL drug information space & 16 & 29 & 45 & 340 & 11.72 \\
\hline
\end{tabular}

the dosing standardization. Related to the pharmacy section, the most units of the pharmacy departments asked drug information was outpatient pharmacy and inpatient pharmacy. This may be related to the absence of library in pharmacy at their units, or there were many patients who needed intervention. Most of the human resources at drug information center were pharmacists, head of drug information centers, and pharmacy technicians. that's related few number of clinical pharmacist operates drug information center. Also, some hospital may utilized pharmacy technician to operate or assisted in operation of the drug information services as alternatives of pharmacists.
Based on the workload analysis of drug information queries, the average number of human resources per each center was found to be less than one, whereas the total number of staff at the drug information centers was found to be greater than what has been calculated. This shows that there a less workload when compared to the staff. This is related to the low number of activities at the drug information centers because the national drug information services have been recently started at the $\mathrm{MOH}$ hospitals. The number of pharmacists in this study were found to be more than what has been reported by Alamri et al. ${ }^{13}$ The average size of the room of drug information services is acceptable with 
Alomi, et al.: National Workload of Network of Drug Information Centers in Saudi Arabia

\begin{tabular}{|c|c|c|c|c|}
\hline No. & Type of Task \& Activity & $\begin{array}{l}\text { Average number of } \\
\text { activities percenter }\end{array}$ & $\begin{array}{l}\text { The average time of } \\
\text { activities per center (hours) }\end{array}$ & FTE \\
\hline I & Central Drug Information Activities & & & \\
\hline 1.1 & Pharmacoeconomic Services & & & \\
\hline I.1.1 & Drug Utilization Evaluation (DUE) & 6.35 & 1.72 & 1.37 \\
\hline I.1.2 & Cost reduction project (Pharmacoeconomics) & 3.61 & 1.67 & 0.76 \\
\hline Subtotal & & 9.96 & 3.39 & 2.13 \\
\hline 1.2 & In-Services Education & & & \\
\hline I.2.1 & Deliver seminar and Presentation or Lecture & 4.50 & 1.26 & 0.71 \\
\hline Subtotal & & 4.50 & 1.26 & 0.71 \\
\hline 1.3 & In-Services Training & & & \\
\hline I.3.1 & Residency Training & 8.75 & 1.98 & 2.16 \\
\hline 1.3 .2 & Pharmacist Training & 8.17 & 2.03 & 2.08 \\
\hline 1.3 .3 & Pharmacy technician training & 6.04 & 1.85 & 1.40 \\
\hline 1.3.4 & Pharmacist Student Training & 8.75 & 1.89 & 2.06 \\
\hline I.3.5 & Pharm D student training & 7.72 & 2.04 & 1.97 \\
\hline I.3.6 & Pharmacy technician student training & 6.00 & 1.70 & 1.28 \\
\hline Subtotal & & 45.43 & 11.49 & 10.95 \\
\hline 1.4 & Drug Information Services & & & \\
\hline 1.4 .1 & Respond to Drug Information Questions & 26.81 & 1.26 & 4.23 \\
\hline Subtotal & & 26.81 & 1.26 & 4.23 \\
\hline 1.5 & Poisoning Information Services & & & \\
\hline I.5.1 & Provider of Poison Information & 4.05 & 0.45 & 0.23 \\
\hline Subtotal & & 4.05 & 0.45 & 0.23 \\
\hline 1.6 & Clinical Researeches and Publication & & & \\
\hline I.6.1 & Perform clinical research, publishing articles & 3.57 & 2.31 & 1.03 \\
\hline I.6.2 & Prepare and Publish Newsletter & 6.00 & 2.23 & 1.67 \\
\hline Subtotal & & 9.57 & 4.54 & 2.7 \\
\hline Grand total & & 100.32 & 22.39 & 20.95 \\
\hline II & $\begin{array}{l}\text { Patient-Specific Drug Information } \\
\text { Activates }\end{array}$ & & & \\
\hline II.1 & ADR (Identification \& Reporting) & 8.68 & 0.57 & 0.62 \\
\hline 11.2 & Medications Errors preventing and monitoring & 14.76 & 0.89 & 1.64 \\
\hline 11.3 & Ambulatory care clinic participation & 6.07 & 1.11 & 0.84 \\
\hline II.4 & CPR team participation & 3.82 & 0.88 & 0.42 \\
\hline 11.5 & Pharmacokinetic consultation & 6.25 & 0.98 & 0.76 \\
\hline 11.6 & Nutrition Support & 6.07 & 0.93 & 0.70 \\
\hline 11.7 & Patient Counseling & 18.41 & 1.49 & 3.43 \\
\hline Total & & 64.06 & 6.85 & 8.41 \\
\hline III & $\begin{array}{l}\text { Administration-Specific Drug } \\
\text { Information Activates }\end{array}$ & & & \\
\hline III.1 & Planning of clinical pharmacy services & 5.92 & 1.70 & 1.26 \\
\hline III.2 & Writing statistical report & 10.58 & 1.68 & 2.22 \\
\hline III.3 & Policies and Procedure design & 8.57 & 2.18 & 2.33 \\
\hline III.4 & Filing of forms/ preparation of minutes & 7.66 & 1.75 & 1.67 \\
\hline
\end{tabular}




\begin{tabular}{|l|l|c|c|}
\hline III.5 & Attending Lectures/ Courses/ Symposium/ Training & 9.32 & 2.46 \\
\hline III.6 & $\begin{array}{l}\text { Helping in Drug Cases from Outside Formulary } \\
\text { system }\end{array}$ & 5.77 & 1.24 \\
\hline III.7 & $\begin{array}{l}\text { Appointments with Pharmaceutical Co. } \\
\text { representatives }\end{array}$ & 5.54 & 1.08 \\
\hline III.8 & Supervising Drug Information Services & 9.75 \\
\hline III.9 & $\begin{array}{l}\text { Participate in Pharmacy and Therapeutic } \\
\text { Committee }\end{array}$ & $\mathbf{2 . 1 9}$ \\
\hline III.10 & Develop update Hospital Formulary & 6.94 & 1.21 \\
\hline III.1I & Setting and evaluating therapeutic guidelines & 5.32 & 1.05 \\
\hline Total & & 6.21 & $\mathbf{1 1 . 4 3}$ \\
\hline
\end{tabular}

the current level of activities, but it is not acceptable to the number of members in the staff, which means there is a need for expansion. This result was found to be lower than what has been reported by Lim et al. ${ }^{15}$ The results of our analysis showed that there is a great demand of FTEs because of number of activities and increased time needed to perform those activities. The second highest amount activities were observed for administration-related activities than that of patientspecific activities. This is an acceptable finding because most of the activities are not directly related to the patient. The highest amount of activity performed by drug information services was observed in case of training services to the pharmacist and pharmacy student; the next highest was the patient answering the drug information queries, whereas third highest was the counseling and attending the educational symposium. The results reflect the actual practice. Those common activities done by drug information pharmacist. Activities such as drug utilization, researches, publication, or direct patient care were taken care by most of the working staff with bachelor's degree, and they were regular training pharmacists and not clinical pharmacists. The actual demand for the drug information FTE for activities was higher than what has been practiced. Because the activities not done all or properly and takes less time. Our results of drug information activities were found to be more than those reported by Alomi; this might be because of the wide range of the center with more additional activities with reflected in reality. ${ }^{16}$ Other findings were difficult to compare due to the lack of information. The workload of drug information centers was high with recommended activities. The drug information centers pharmacists needed more education and training to focus on more activities related to the drug information services with cost avoidance and prevention of drugrelated problems.

\section{CONCLUSION}

Despite the high workload of drug information services, there is a great demand for personnel related to human resources, facilities, and financial support. Targeting to review all requirements of drug information services is highly recommended at MOH in Kingdom of Saudi Arabia.

\section{ACKNOWLEDGMENT}

None.

\section{CONFLICT OF INTEREST}

None.

\section{ABBREVIATIONS}

ACCP, American College of Clinical Pharmacy; FTE, full-time employee; KSA, Kingdom of Saudi Arabia; $\mathrm{MOH}$, Ministry of Health; CBAHI, Saudi Center for Accreditation of Healthcare Institutions.

\section{ORCID ID}

Yousef Ahmed Alomi (iD https://orcid.org/0000-0003$1381-628 \mathrm{X}$

\section{REFERENCES}

1. Alomi YA. National Drug Information Center Program at Ministry of Health in Saudi Arabia. Adv Pharmacoepidemiol Drug Saf. 2016;5(1):1-2.

2. YA A, Mudaiheem H A. National Drug Information Center Services through Ministry of Health Hotline Calling Center (937) in Saudi Arabia. Adv Pharmacoepidemiol Drug Saf. 2016; 5(1):1-7.

3. Alomi YA, Almudaiheem HY, Alarnous T, Alshurei S, Alsharafa A, Alzahrani $\mathrm{T}$, et al. Cost-Efficiency of National Drug Information Center Through Ministry of Healh Hotline Calling Services (937) in Saudi Arabia: Application of American Model. Value Health. 2015;18(7):A735. 
4. Skoutakis VA, Wojciechowski NJ, Carter CA, Hayes JM, Hudson BL, Martin JA. Drug Information Center network: need, effectiveness and cost justification. Drug Intell Clin Pharm. 1987; 21:49-56.

5. Lyrvall H, Nordin C, Jonsson E, Alvan G, Öhman B. Potential savings of consulting a drug information center. Annals of Pharmacotherapy. 1993;27:1540.

6. Kinky DE, Erush SC, Laskin MS, Gibson GA. Economic impact of a drug information service. Ann Pharmacother. 1999; 33(1):11-6.

7. Marrone CM, HeckAM. Impact of a Drug Information Service: Practitioner Hours Saved. Hosp Pharm. 2000; 35(10):1065-70.

8. Ponampalam R, Loh CS. Cost benefits of the Drug and Poison Information Centre in preventing unnecessary hospitalisation: The Singapore experience. Hong Kong J Emerg Med. 2010; 17(1):45-53.

9. Brown JN. Cost Savings Associated With a Dedicated Drug Information Service in an Academic Medical Center. Hosp Pharm. 2011; 46(9):680-4.

10. Bond CA, Raehl CL, Franke T. Clinical pharmacy services, pharmacy staffing and the total cost of care in United States hospitals.
Pharmacotherapy. 2000; 20(6):609-21.

11. Ghaibi S, Ipema H GM. ASHP Guideline on The Pharmacist's Role in Providing Drug Information. Am J Heal Pharm. 2015;72:573-7.

12. Bond CA, Raehl CL, Franke T. Clinical pharmacy services, pharmacist staffing and drug costs in United States Hospitals. Pharmacotherapy 1999; 19(12):1354-62.

13. Alamri S, Ali Al Jaizani R, Naqvi A, Ghamdi M. Assessment of Drug Information Service in Public and Private Sector Tertiary Care Hospitals in the Eastern Province of Saudi Arabia. Pharmacy. 2017; 5(3):37.

14. Matuszewski KA, Windisch PA. Drug information activities in academic health centers: A 1996 survey. Ther Innov Regul Sci. 1998;32(2):539-46.

15. Lim LY, Chui WK. Pharmacist-operated drug information centres in Singapore. J Clin Pharm Ther. 1999;24(1):33-42.

16. Alomi YA. Workload Analysis And Staffing Requirement Of Clinical Pharmacy Services At Ministry Of Health In Saudi Arabia. Value Health. 2016;19(7):A466.

Cite this article as: Alomi YA, Alghamdi SJ, Alattyh RA. National Workload Analysis of Network of Drug Information Centers at Ministry of Health Hospitals in Saudi Arabia. Int J Pharmacol. Clin. Sci. 2018;7(4):17-25. 